\title{
Quasar X-Ray Spectra Revisited: Erratum
}

\section{Citation}

Shastri, P., B. J. Wilkes, M. Elvis, and J. McDowell. 1994. “Quasar X-Ray Spectra Revisited: Erratum." The Astrophysical Journal 431 (August): 901. doi:10.1086/174541.

\section{Published Version}

doi:10.1086/174541

\section{Permanent link}

http://nrs.harvard.edu/urn-3:HUL.InstRepos:30212138

\section{Terms of Use}

This article was downloaded from Harvard University's DASH repository, and is made available under the terms and conditions applicable to Other Posted Material, as set forth at http:// nrs.harvard.edu/urn-3:HUL.InstRepos:dash.current.terms-of-use\#LAA

\section{Share Your Story}

The Harvard community has made this article openly available.

Please share how this access benefits you. Submit a story.

Accessibility 


\section{ERRATUM}

In the paper "Quasar X-Ray Spectra Revisited" by P. Shastri, B. J. Wilkes, M. Elvis, and J. McDowell (ApJ, 410, 29 [1993]), there is an error in the flux density levels in Figures $4 a$ and $4 b$. As a result of an error during rebinning of the optical spectrophotometry data, the flux density levels in those two figures are a factor of 5 lower then their actual value. 